\title{
The Development of an Internal Supervision Model Using the Professional Learning Community for Educational Supervisor of Graduate Diploma in Teaching Profession Program
}

\author{
Pairote Boriboon ${ }^{1}$, Chalard Chantarasombut ${ }^{2} \&$ Pha Agsonsua ${ }^{2, *}$ \\ ${ }^{1} \mathrm{Ph} . \mathrm{D}$. Candidate in Educational Administration, Thailand \\ ${ }^{2}$ Faculty of Education, Northeastern University, Khon Kean, Thailand \\ *Correspondence: Faculty of Education, Northeastern University, Khon Kean, Thailand. Tel: 66-4322-2959. E-mail: \\ dba.neu@gmail.com
}

Received: March 8, 2020

Accepted: April 6, $2020 \quad$ Online Published: April 21, 2020

doi:10.5430/wje.v10n2p163

URL: https://doi.org/10.5430/wje.v10n2p163

\begin{abstract}
The objectives of this research were to: 1) study the current and desirable situations of supervision for graduate diploma in teaching profession program, 2 develop the internal supervision model using professional learning community for educational supervisor of graduate diploma in teaching profession program, and 3) evaluate the efficiency of the developed model.The samples were 49 educational supervisors and committees of graduate diploma in teaching profession program. The instrument was handbook of internal supervision model developed by using the professional learning community. Statistics used were percentage, mean, standard deviation, modified priority needs index, efficiency index, and t-test for dependent samples. The finding srevealed that:

1) The current situation of internal supervision of graduate diploma in teaching profession program was in "High" level. In addition, the desirable situation was found in the"Highest" level. When considering each aspect, it was found that the aspect with highest emergency need for development was the planning with the $\mathrm{PNI}_{\text {modified }}$ of 0.40 . The second one was the implementing with the $\mathrm{PNI}_{\text {modified }}$ of 0.36. 2) The developed model was evaluated in the "Highest" level in terms of the propriety, feasibility, and utility.It was integrated in 6 steps including: (1) Preparing, (2) Planning, (3) Implementing, (4) Reflecting, Improvement, and Evaluation, (5) Reinforcing, and (6) Concluding and Reporting. 3) The results of the trials were: (3.1) The efficiency of process and product $\left(\mathrm{E}_{1} / \mathrm{E}_{2}\right)$ were 84.67/ 83.00 which was higher than the specified criterion 80/80. (3.2) The posttest score was significantly higher than the pretest one at level of p-value $<0.01$. (3.3) The satisfaction on the developed model was in the "Highest" level. When considering each aspect, it was found that planning had the highest mean score, while implementing was found in the second order, and reflecting, improvement, and evaluation had the lowest mean scores.
\end{abstract}

Keywords: internal supervisison model, professional learning community, educational supervision clinique the route to excellence: ESC

\section{Introduction}

According to the Constitution of the Kingdom of Thailand 2017, the Revised Issue ( $2^{\text {nd }}$ Issue) 2002 of the National Education Act 1999, the 20 Year National Strategy, the $12^{\text {th }}$ Issue of National Economic and Social Development Plan (2017-2021), the National Education Plan (2017-2036), and the National Education Standard 2018, all of them aimed at the human development of the Thai Society in terms of strong national basis, the readiness in physical, mental, intellectual, and skill during the $21^{\text {st }}$ century, the ethics and morality, the legal respect, the leadership, the conservation in being Thai as well as awareness of universal context. Moreover, the goals of educational management also focusing on enjoying life-long education, and developing the learning style of Thai people to become a learning society leading to collaborative innovation development for improving the quality of life as well as improving society. Consequently, the Office of Higher Education agreed to improve the higher education standard to be relevant to National Education Standard for using as mechanism in Ministry level, Higher Education Commission level, and Working Unit level for promoting the Educational Quality Assurance to be congruent with the above rationales through continuous monitoring, follow up, investigation, evaluation, and development. The Higher Education Standard would cover the 
student outcome, research and innovation, academic service for society, art and culture, and Thai Identity, and administration and management based on potentiality as well as identity of institutional type by emphasizing on responsibility for society as well as accountability in order to accomplish the major goal of Educational Management so that the graduates at the higher educational level would have the characteristics of Thai people which was relevant to the National Strategy, and would be important powerful development for Thailand to be secure, prosperous, and sustainable. (Ministry of Education, 2018)

The Council Act for Teachers and Educational Staff 2003 also promoted the major goals specifying the educational professions including teaching as well as school administrators to become a controlled profession, a supervision profession to be another controlled profession as specified by Ministry Law. The teachers, school administrators, educational administrators, and staff (Educational Supervisors) have played an important role for national educational management. Therefore, they should be knowledgeable and competent by having a special set of skill sin the Educational Profession, professional ethics, and behavior in accordance with their higher profession. The Teacher Council as Teaching Profession Council and Educational Staff was designated to have responsibility and duty in determining the professional standard and code of conduct, monitoring and taking care of educational profession, resigning, stopping, and revoking the professional license, certifying diplomas, certificates, and educational degrees, and certifying the skill as professionals. The implementation was based on the aforementioned laws. The Teacher Council of Thailand issued the regulation for professional license 2013 (4 $4^{\text {th }}$ October 2013), the regulation of Professional Standard, and Code of Conduct 2013 (12 ${ }^{\text {th }}$ November 2013). Moreover, they established the Teacher Council Board to certify the educational diplomas and certificates for professions in 2014, and various related issues for educational staff and persons to practice these principles in their professions. (Secretariat of the Teacher Council of Thailand, 2013)

Professional Learning Community was a strategy for major Educational Management Reform as a guideline for developing the learning management into Educational Change during the $21^{\text {st }}$ century. It was a major instrument for Educational Management Reform into learning during the $21^{\text {st }}$ century of The United State of America and Singapore (DuFour, Eakey, and Many, 2006). The strategies of Professional Learning Community were used as instruments for moving and implementing until satisfactory results were obtained. In addition, teaching profession development in many schools also implemented the professional learning community such as Arsomsilp Institute of the Arts, and Roong Aroon School which were established in Thailand, (Surapol Dharma Romdee et al., 2010). Moreover, the project "Teacher for Student" of the Foundation of Sodsri-Saritwong (nd) also created the teaching professional development by using the approach of professional learning community. (Wichan Panich, 2012).

As mentioned about the rationale and the benefit professional learning community above, the researchers, therefore, were interested in studying the current situation and desirable situation of supervision for the graduate diploma in teaching profession program, based on factors of supervision management, guidelines for developing the internal supervision model developed by integrating the profession learning community into the Internal Supervision Model to move further in a continuous and sustainable manner. Research Objectives are as follows: 1) To study the current situation and desirable situation in supervision of graduate diploma in teaching profession program. 2) To develop the internal supervision model developed by using professional learning community for educational supervisor of graduate diploma in teaching profession program. 3) To evaluate efficiency of internal supervision model developed by using professional learning community for educational supervisor of graduate diploma in teaching profession program.

\section{Delimitation of Research}

\subsection{Population and Samples}

- The population of this study consisted of 309 educational supervisors and the committees of graduate diploma in teaching profession program, from 14 institutions including 228 educational supervisors and 81 program committees.

- The samples were 2 groups, total of 49 persons, by using the calculated formula in searching for samples based on criterion (Boonchom Sri-sa-ad, 2013) as follows: 1) The key informants were 25 educational supervisors and 10 program committees from 5 Rajabhat Universities. 2) The key informants were 10 educational supervisors and 4 program committees from 2 private universities

\subsection{Research Variables}

- Independent Variable was the internal supervision model developed by using professional learning community.

- Dependent Variables were: 1) knowledge and comprehension,2) implementing the skill, and 3) satisfaction. 


\subsection{Duration of Research}

The internal supervision model was implemented by using professional learning community for educational supervisors and committee of graduate diploma in teaching profession program, during the 2017 academic year.

\subsection{The Applied Development Model}

The model used for internal supervision by using professional learning community for educational supervisors and committees of graduate diploma in teaching profession program, consisted of 6 steps of internal supervision process including: 1) preparing, 2) planning, 3) implementing, 4) reflecting, improving and evaluation, 5) reinforcing, and 6) concluding and reporting. In addition, the professional learning community supported 6 factors including: 1) the shared vision, 2) collaborative teamwork, 3) shared leadership, 4) professional learning and development, 5) caring community, and 6) supportive structure as the developed innovation for internal supervision.

\section{The Conceptual Framework of Research}

The conceptual framework concluded 3 steps which were: 1) the study of the current situation and desirable situation in internal supervision, 2) the development of internal supervision model developed by using the professional learning community, and 3) the evaluation of efficiency in using the internal supervision model developed by using the professional learning community with reference to: Hord, (1997); Hargreaves, (2003); Little \& McLaughlin, (1993); Kotter \& Cohen, (2002); Olivier \& Hipp, (2006); Thompson, Gregg \& Niska, (2004); DuFour, (2006); Sergiovannit, (1994); Eastwood \& Louis, (1992); Stoll \& Louis, (2007); Chantarasombut, C. (2017); Panich, W. (2012); Sri-sa-ad, B. (2013). as shown by Figure 1.

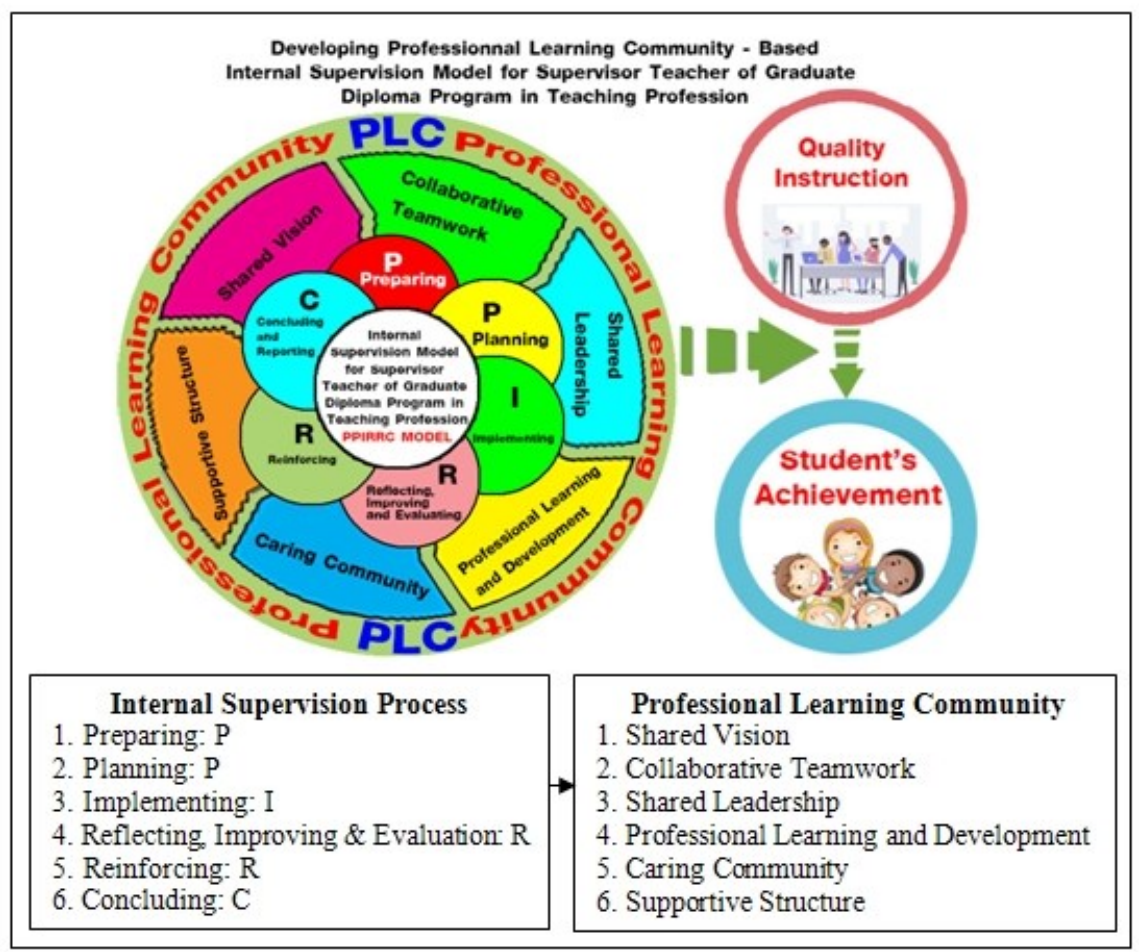

Figure 1. Conceptual Framework of Basic Research

\section{Research Methodology}

\subsection{The Construction and Development of Research Instruments}

The methods and steps for the construction of instruments were as follows:

a. The Questionnaire on the current situation and desirable situation of internal supervision was constructed by researchers based on conceptual framework as well as issues to be investigated the propriety of factors and indicators of internal supervision by using professional learning community. 
- The following steps of constructions were present in the construction and searching for quality: (1) The techniques for constructing the questionnaire based on factors and indicators of internal supervision by using the professional learning community were studied. (2) The obtained data were evaluated based on the content framework. (3) The tentative questionnaire was constructed and presented to thesis committee for consideration and investigation whether it was correct or covered the content. It was adapted based on comments and suggestions received. (4) The content validity testing was done by considering the congruence of all questions in the questionnaire based on factors and indicators of internal supervision by using the professional learning community. In this step, the analysis of IOC basing on the opinion of the same experts was implemented. Then, the results of the Index of Congruence (IOC) of the evaluation from evaluated by experts item by item was higher than 0.5. (Boonchom Sri-sa-ad, 2013). It was also found that the IOC values could be ranged between 0.60-1.00. (5) The results from the IOC on factors and indicators of internal supervision model developed by using process of professional learning community was presented to the thesis committees for consideration and revision. (6) The final draft of questionnaire on factors and indicators of internal supervision model developed by using process of professional learning community was finally conducted.

- For the data collection, the researchers contacted and coordinated with experts, and collected data by making meetings to analyze and conclude the issues for improving the research conceptual framework.

- Data from evaluation form were implemented and analyzed as follows: (1) The Questionnaires of factors and indicators from data collection, were checked and scored. The scoring criteria were as follows: (Boonchom Sri-sa-ad, 2013).

$\begin{array}{ll}\text { "The Highest" } & \text { level equaled } 5 \text { points } \\ \text { "High" } & \text { level equaled } 4 \text { points } \\ \text { "Moderate" } & \text { level equaled } 3 \text { points } \\ \text { "Low" } & \text { level equaled } 2 \text { points } \\ \text { "the Lowest" } & \text { level equaled } 1 \text { point }\end{array}$

(2) The obtained data from questionnaire were analyzed by calculating the mean and standard deviation by using computer program, item by item. The criteria for interpreting were as follows: (Boonchom Sri-sa-ad, 2013).

\section{Average score}

4.50-5.00

$3.50-4.49$

2.50-3.49

$1.50-2.49$

1.00-1.49

\section{Level of awareness and preparation}

Propriety was in "the Highest" level

Propriety was in "the High" level

Propriety was in "the Moderate" level

Propriety was in "the Low" level

Propriety was in "the Lowest" level

b. For collecting during the workshops, all stakeholders including educational supervisors, program committee, and educators were called for brainstorming and analyzing the current situation as well as desirable situation in internal supervision. The issues to be analyzed, were determined based on factors studied by researchers as well as investigated by experts.

- The construction and validation of instrument consisted of the following steps: (1) The techniques for constructing the instrument for data collection based on factors and indicators of internal supervision by using the professional learning community for educational supervisors were studied. (2) The data collection form based on framework of content to be required was constructed. (3) The tentative data collection form was presented to the thesis committees for consideration and investigation whether it was correct or covered the content. Then, the recommendations were used to make improvements and revisions. So that the data collection form would be more comprehensive. (4) The quality in content validity was investigated by experts' consideration for congruency between question issues in data collection form based on factors and indicators of internal supervision by using the professional learning community. In this step, the IOC analysis of opinion from the same experts who investigated the model also investigated the Content Validity. Then, the IOC was searched for by analyzing the Index of Congruence (IOC) of data collection form, item by item, by considering the questions with IOC values which higher than 0.5. (Boonchom Sri-sa-ad, 2013). It was found that the IOC values could be ranged between 0.60-1.00. (5) The data collection form of factors and indicators for internal supervision by using the professional learning community was improved based on the experts' recommendations. Then, it was presented to the thesis committees. (6) The data collection form of factors and indicators for internal supervision by using the professional learning community, was established. 
- For collecting during the workshops, all stakeholders including educational supervisors, program committee, and educators were called for brainstorming and analyzing the current situation as well as desirable situation in internal supervision. The issues to be analyzed, were determined based on factors studied by researchers as well as investigated by experts.

- For the data implementation and analysis, they were implemented by content analysis.

c. The questionnaire with closed-ended questions was administered to ask for the opinion of 49 persons including: 1) from 5 Rajabhat University Groups, the key informants were 5 educational supervisors from each institution total of 35 persons, and 2 program committees from each institution, total of 14 persons. There were steps of instrument construction as follows:

- The instrument was a questionnaire asking for opinion on current situation and desirable situation of internal supervision, there were 2 parts as follows:

Part 1, it asked for the respondents' demographic data including gender, position, and seniority.

Part 2 of the questionnaire asked for the opinion on current situation and desirable situation of internal supervision. It was rating scale based on Likert's 5 level scale including: The Highest, High, Moderate, Low, and the lowest levels respectively.

- The construction and evaluation for quality were as the following steps: (1) The approaches, theories, and principles for constructing the questionnaire were studied. (Boonchom Sri-sa-ad, 2013; Sombat Tai-reu-kam, 2003). (2) The questionnaire on the current situation and desirable situation of internal supervision was constructed based on conceptual framework resulting from content synthesis in documents and investigating its correctness by thesis committees. (3) The tentative questionnaire was presented to 5 experts for considering the congruence of Content Validity of questionnaire by using the IOC (Index of Congruence. The questions with IOC values in higher level than 0.50 were selected. Then, the criteria were presented to the thesis committees for improvement and revision. It was found that the IOC values could be ranged between 0.60-1.00. (4) The revised questionnaire was established as an issue and evaluated with instructors in North Eastern University. The obtained data were analyzed in searching for Item Discrimination, and Reliability of total issue by searching for Cronbach's Alpha Coefficient. It was found that the Item Discrimination values were ranged between $0.34-0.82$, while the Reliability of total issue was $=0.87$. (5) The complete questionnaire was established to ask for the opinion of educational supervisors as well as program committees based on specification in order to collect the field data.

\subsection{Data Analysis}

- The Efficiency of Process and Efficiency of Product in knowledge for internal supervision model were analyzed by using E1/E2 formula as follows (Chaiyong Promwong, 1994: 479-498):

$$
\begin{aligned}
& \mathrm{E}_{1}=\frac{\sum \mathrm{X} / \mathrm{N}}{\mathrm{A}} \times 100 \\
& \mathrm{E}_{2}=\frac{\sum \mathrm{F} / \mathrm{N}}{\mathrm{B}} \times 100
\end{aligned}
$$

- The Efficiency of Process and Efficiency of Product in knowledge for internal supervision model were analyzed by calculating the mean and t-test (dependent sample) for comparing the pretest and posttest. (Boonchom Sri-sa-ad (2003,p.109)

- The Effectiveness Index of Process and Efficiency of Product in knowledge for internal supervision model, were analyzed by calculating the Mean and t-test (Dependent Sample), were analyzed by using the Efficiency Index of Chaiyong Promwong (1994, p.479-498) to search for the Effectiveness Index as follows:

Effectiveness Index (E.I) = The sum of posttest scores - The sum of pretest scores

$$
\text { (Number of students X Full scores ) - The sum of pretest scores }
$$

- The satisfaction on internal supervision model developed by using the Professional learning community for educational supervisors of graduate diploma in teaching profession program was analyzed by using the mean ( $\bar{X})$, and standard deviation (S.D.) using the criterion for measuring the satisfaction level based on Likert's criterion of Boonchom Sri-sa-ad (2010, p.101-103). 


\section{Results}

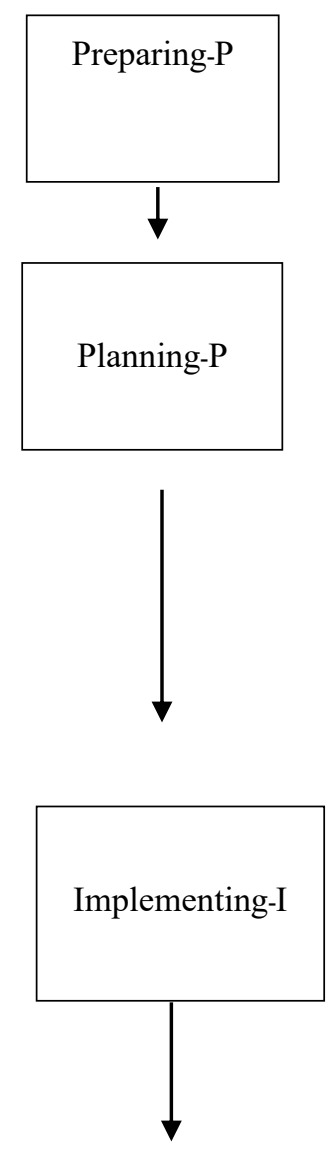

- Collaborative study of current authentic supervision in the present.

$\circ$ Analyzing the good point and weak point to be precise, and analyzing the common direction and goal.

- Analyzing the prominent achievement and one that needed to be corrected of knowledge management being occurred in students.

$\circ$ Conference in planning for implementing, reviewing, decision making, evaluating, and being responsible for working.

- Specifying the problem and need, prioritizing the significance of problem.

- Specifying the solution of problem, selecting the issues to be improved/developed and search for guidelines of development.

○ Preparing the organization, designing supervision, preparing staffs for

○ providing knowledge in supervision and constructing professional learning community for leading staffs in supervision.

- Allocating the budget for supportive resource of supervision proves.

○ Cooperating with related working unit.

○ Establishing the project, and proposing the development project for learning enhancement individually and group.

- Holding the conference for understanding before supervision based on specified plan.

- Supervising the knowledge management for supervision participants, and teaching observation.

○ Administration, control, monitoring and assessment

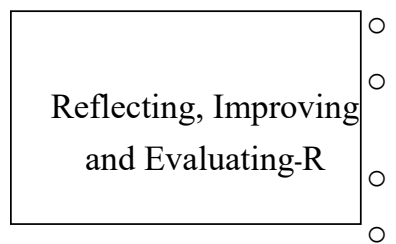

Holding conference for analyzing data after teaching observation.

- Reflecting the implementation systematically based on supervision issues with care and creative climate.

- Revising and improving or developing based on reflection.

Systematic evaluation in overall.

- Providing opinion for future improvement and development.

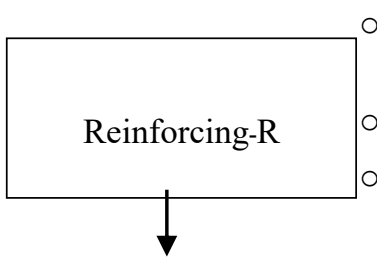

- Being polite and gentle, visiting, talking, greeting, and warm thoroughly. Paying attention to everyone and collaborating in being responsible for performance.

- Reinforcing in teaching supervision.

- Recognizing and glorifying by advertising the honor, and glorifying the knowledgeable persons for providing the instruction very well.

Concluding and

Reporting-C

- Providing the systematic discussion in implementation.

- Assigning the group for speaking and sharing among educational supervisors and supervision participants.

- Systematic concluding the performance, and investigating the right thing of concluded performance and supplementary recommendations for development.

- Reporting the performance and advertising the implementation findings to the public. 
a. The current situation and desirable situation in internal supervision of graduate diploma in teaching profession program were as follow:

- The prioity of need for developing the internal supervision of graduate diploma in teaching profession program, in overall, was $=0.06$. When considering in each aspect, it was found that the need for implementing was in the highest level, while the second order included he reflecting, improving, and evaluation, planning, preparing, and reinforcing.

- The priority of need for using the process of professional learning community, in overall, was $=0.42$. When considering in each aspect, it was found that the need for collaborative teamwork was in the highest level. The second order included the shared vision, caring community, vocational learning and development, and supportive structure respectively.

b. The internal supervision model was developed by using the professional learning community for educational supervisors, evaluated by scholars and experts included 6 steps which were: 1) preparing, 2) planning, 3) implementing, 4) reflecting, improving, and evaluation, 5) reinforcing, and 6) concluding and reporting as well as 25 sub-activities, in overall, the propriety, feasibility, and utility, were in "The Highest" level as shown in Figure 2.

c. The internal supervision model developed by using professional learning community was tried out with target group based on implementation plan. It was found that the efficiency of the developed model was as follows:

- The educational supervisors and program committees consisted of efficiency of process and efficiency of product of knowledge $(E 1 / E 2)=84.67 / 83.00$ which was higher than the specified criterion $80 / 80$.

- The posttest score of knowledge and comprehension in the internal supervision and professional learning community was significantly higher level than pretestat the level of (p-value $<0.01$. Their knowledge scores were increased for 9.57 points (95\% CI: 8.63-10.52).

- The posttest scores of the educational supervisors and program committees on the internal supervision and professional learning community was significantly higher than the pretest at the level of p-value $<0.01$. Their knowledge scores were increased 1.54 points. (95\% CI: $1.35-1.72)$

- The educational supervisors and program committees had their implemented skill after sub-activities learning in high level as specified criterion for $80 \%$.

- The educational supervisors and program committees were satisfied on the internal supervision and professional learning community for educational supervisors of graduate diploma in teaching profession program. The satisfaction level was found in the highest level. ( $\bar{X}=4.59$, S.D. $=0.65$ ). When considering in each aspect, it was found that the planning had the Highest level of mean score of $(\bar{X}=4.74$, S.D. $=0.61)$. The second order was the implementing with the mean score of $(\bar{X}=4.64$, S.D. $=0.64)$, while the steps having lowest level of mean score $(\bar{X}=4.39$, S.D. $=0.73)$ include deflecting, improving, and evaluation.

\section{Discussions}

According to research findings, they could be discussed as follows:

1) The current situation and desirable situation in supervision of graduate diploma in teaching profession program. There were 6 major factors including: 1) Preparing, 2) Planning, 3) Implementing, 4) Reflecting, Improving, and Evaluation, 5) Reinforcing, and 6) Concluding and Reporting. In addition, there were 6 factors of professional learning community containing: 1) Shared Vision, 2) Collaborative Teamwork, 3) Shared Leadership, 4) Professional Learning and Development), 5) Caring Community, and 6) Supportive Community Structure. It might be due to the index of priority in need for developing the internal supervision was implemented based on steps in studying the current situation and desirable situation leading to the analysis of need based on principle and technique of Suwimon Wongwanich (1999). This was supported by the study of Atid Chaisirin (2019: 196-197) who found that the index of priority in Need for developing the internal supervision, in overall, was $=0.06$. When considering in each aspect, it found that the implementation had the highest level of need. The second order included the concluding and reporting, reflecting, improving, and evaluation, preparing, and planning. The findings of this research indicated the need (PNI Modified) for developing the internal supervision for the first priority. It was supported by research findings of "The Study of Situation and Problem in Internal Supervision of Schools under Educational Municipal Area 10, Ubon Rachatani Province. (Mintra Lai-sa-nit-seree-koon, 2014; Kiitisak Ang-ka-na-win, 2018) which found that low level of problem was in the implementing according to the plan, in overall and each item. The item with highest level of problem included: the monitoring and following up the implementation based on steps as well as the appointed duty regularly, the supervision was not implemented in accordance with a specified plan for periodical supervision, 
continuous evaluation, the understanding with supervision participants and supervisors with care, the awareness development for staffs to be more responsible, the committee were not precisely appointed, the date and time for teachers who needed the supervision for specifying the supervision plan collaboratively, the significant problems were not prioritized, the solutions were not searched for, the problem of internal supervision that was not democratic, the work implementation was not based on schedule/ work plan/internal supervision plan, the schools assigned the administrators with inefficient system and communication for improving the relationship among school teachers. (Tantima Pongprom, 2015).

Sergiovanni and Starratt (2007) stated that the adjustment of educational supervision that there were 3 levels of educational supervision: 1 the In-service Training, 2) Professional Development, and 3) Renewal. These 3 levels of implementation were useful for educational supervision. However, the implementation in Level 2 and Level 3, were strategies for development rather than training only.

Likewise, the findings of this study also indicated that the shared leadership was needed for using the process of professional learning community for the first order as well as the findings in the study of professional learning community during the $21^{\text {st }}$ century based on school context in Thailand. Woralak Chukamnerd et.al. (2014)found that there was logical continuous relationship in sequence based on 6 aspects of major factors including: (1) caring community based on Thai style, caused the trust and listening with each other, (2) leadership aroused the potentiality in revealing the transformational leaders, (3) believed vision caused the compass energy of shared vision, (4) the open system of collaborative energy aimed for students leading to the owner of learning, (5) the professional learning team system for teacher's maturity and spirit caused the common intention in professional development, (6) the collaborative learning area based on authentic work caused the learning culture for changing on the basis of authentic work when each area obtained continuous development until it was normal way of organization. David (1997) also found that the transformational administrator's behavior and implementation could affect both of individual learning as well as group learning. Besides, the researchers also found the unique characteristic of research findings: 1) the team leaders played their role as transformational leaders, 2) the transformational leaders had to develop the learning climate by enhancing the collaboration and using the team potentiality, 3) the leaders behaved appropriate behavior, 4) there was challenging for team to set the question and share their opinion, 5) there was knowledge sharing and information receiving for improving the team learning, 6 ) the leaders reinforced their team's opportunity in overall learning as well as overall implementation and decision making which could affect the system, and 7) the leaders encouraged their members to have opportunity in learning how to be leaders by themselves.

It was supported by condition in using the professional learning community in school successfully which 3 conditions were needed to be considered: 1) the condition of school administrator's leadership, 2) the condition of potentiality and infrastructure, and 3) the condition of staff's relationship and competency including 5 factors of success including: the precise vision, the preparation of human system, work system, and supportive system for enhancing the implementation by creative communication, development in collaborative organizational culture, and belief in what was done as well as teaching profession,. The school administrators should play an important role in creating the changing climate and context, developing and communicating the shared vision for changing, planning providing the resources, supporting the teacher's professional development, following progress and helping continuously (Siripan Suwanmanka, 2017; DuFour Eaker and Many, 2010).

2) The internal supervision by using the professional learning community for educational supervisors of graduate diploma in teaching profession program indicated both of efficiency and effectiveness in process and product which $\mathrm{E} 1=84.59$ and $\mathrm{E} 2=82.26$ which were higher than the specified $80 / 80$ criterion. It was caused by the model that was developed by studying the rational, approach, related theories and research literatures. Moreover, it was developed the internal supervision model developed by using professional learning community for educational supervisors of graduate diploma in teaching profession program. In addition, there was a developed handbook for using the internal supervision model developed by using professional learning community for educational supervisors of graduate diploma in teaching profession program, in implementing based on sub-activities, and investigating, revising, and improving based on experts' recommendations. The research findings found that the quality of developed model, in overall, was in "the Highest" level. Furthermore, considering each aspect, found that the quality of Propriety, feasibility, and Utility was in "the Highest" level. It was supported by the study of Suchitra Inreungsri's (2011: 70-71) study in "The Development of Module Lesson in Life and Culture Subject for High Vocational Certificate of Automotive Industry Technician College," the research findings found that: 1) the Learning module consisted of rational, principle, objective of basic knowledge in foundation of assessment, learning activity, posttest evaluation, and remedial learning, had efficiency as criterion. (83.88/85.96); Supee Donpraipan (2013: 48) studied the Development of Learning Module titled "Sufficiency Economy Philosophy for Matayomsuksa 2 Students," the research findings 
found that the efficiency of module lesson titled "Economic Theory," was $=79.66 / 82.77$. Moreover, Chalard Chantarasombat (2018) studied the development of learning module titled "Educational Policy, Strategy, and Strategic Plan for Students," the efficiency of process and knowledge product (E1 / E2) was $=84.67 / 83.00$ which was higher than the specified criterion $80 / 80$.

- The posttest knowledge and comprehension on internal supervision by using the professional learning community, was significantly higher than the pretest at the level of 0.01 . It might be due to the fact that the educational supervisors and program committees was implemented based on sub-activities in handbook of implementation strictly and continuously including the conference for implementation planning, revising, decision making, evaluating and being responsible, specifying the problem and need, prioritizing the significant problems, specifying the solution of problems, selecting the issues to be improved/developed, and searching for guidelines in developing, collaborating in preparing the organization, designing the supervision, preparing the staffs for being provided knowledge in supervision as well as constructing the professional learning community for leading staffs in supervision and collaboration with related work units.

- The educational supervisors and program committees had their posttest skill after sub-activities in high level as specified criterion. This might be due to the fact that the co-researchers followed the handbook of internal supervision by using the professional learning community for educational supervisors of graduate diploma in teaching profession program focusing on implementation through Before Action Review (BAR) and After-Action Review (AAR), consequently, the learning was occurred. In addition, the quality of continuous internal supervision as Professional Learning Community (PLC) was increased since it was new for educational institutions to develop the innovation, search for internal supervision model developed by using the professional learning community for educational supervisors of graduate diploma in teaching profession program, in concrete form. It was supported by Chalard Chantarasombat at.al.' (2018: 18-35) study in "The Development of Innovation for Enhancing Learning Achievement of School, under Nakon Panom Primary Educational Service Area 2," which found that the network construction in developing the quality of school administrators, teachers, and related persons for improving the level of educational quality in higher level by providing both of formal and informal internal supervision as well as online system continuously.

3) The educational supervisors and program committees were satisfied on the internal supervision model developed by using the professional learning community for educational supervisors of graduate diploma in teaching profession program, in overall, in the "High" level. This might be due to the fact taht before implementation, there were activities for collaboration, participation in supervision to be developed as network for authentic and continuous movement. After that, the internal supervision model developed by using the professional learning community for educational supervisors of graduate diploma in teaching profession program was developed following planning, implementing based on the plan, investigating and evaluating, and concluding the lesson. As a result, the co-researchers were more responsible and viewed that it was necessary to work for solving the problem at work site based on role and function. In addition, the professional ethics were developed. Therefore, the satisfaction on internal supervision model as well as innovation of internal supervision by using the professional learning community were occurred. It was supported by Chalard Chantarasombat et.al' (2018: 239-240) research study in "The Development of Innovation for Enhancing the Learning Achievement of Schools, under Nakon Panom Primary Educational Service Area 2" which found that the research participants' satisfaction, it was in "the Highest" level. It might be because of the development of professional learning community as network in school level and group level. The group was suitable for and congruent with local context and situation. The participative working in new dimension from development of work site for quality classroom and quality school leading to synergy of modeled teachers, modeled administrators, educational supervisors, target group, academics in higher education could lead to the Educational Supervision Clinique: The Route to Excellence (ESC). Furthermore, the knowledge management led to the development of professional learning community (PLC) by applying the innovation for enhancing the school's learning achievement through the development of leading academics of major learning substances as well as the enhancement of supervisor and coach through 7 steps of implementation which were: 1) the participatory synergy and Memorandum of Understanding (MOU), 2) the study and analysis of data, 3) the development of situation and indicator, 4) the planning and network development, 5) the presentation of design and implementation of basic knowledge management, 6) the trying out and enhancement in overall body of knowledge/learning community, and 7) the continuous sharing and development into learning origin. 


\section{Recommendations}

\subsection{The Policy Recommendations}

1) The internal supervision model developed by using the professional learning community, should be advertised by higher education institutions and related work units. In addition, the handbook as well as supplementary documents for model using, should be advertised for being used by related working units further.

2) The supervision committees should be appointed by the higher education institutions and related work in order to follow up and evaluate the internal supervision by using the professional learning community for educational supervisors ofgraduate diploma in teaching profession program, and report the development findings.

3) The steps in studying of current situation and needs, consisted of major findings which every administrator had to be informed and aware of significance.

4) The network of educational instructors and educational supervisors should be constructed by higher educational institutions commendations for shared learning in the whole system.

\subsection{Recommendations for Model Application}

The usage of internal supervision model developed by using the professional learning community for educational supervisors of graduate diploma in teaching profession program, should be aware of its significance and needs by higher education institutions and related work units, the educational supervisors and program committee should collaborate in thinking, planning, implementing, evaluating, and getting benefit in every step.

\subsection{Recommendations for Future Research}

1) The internal supervision model developed by using the professional learning community for graduate diploma in teaching profession program from this study, should be tried out by comparing with the findings in guidelines of internal supervision and other programs.

2) The internal supervision model developed by using the professional learning community for graduate diploma in teaching profession program, should be developed for using in various programs as well as levels.

3) The extended study from internal supervision model developed by using the professional learning community for graduate diploma in teaching profession program, should be conducted in other educational institutions in Regional Level or National Level further.

\section{References}

Chantarasombat, C. (2019). Module Lesson Development: Educational Policy, Strategy, and Strategic Plan (EDA6201) for Master Degree Students of Master Program in Educational Administration. Journal of Education. Mahasarakam University, 14(1), January-March 2020.

Chantarasombat, C., Udomboonyanupab, N., \& Songsri, C. (2018). Innovative Development for Enhancing the Learning Achievement of Schools, under Nakon Panom Primary Educational Service Area Office 2. Journal of Education. Mahasarakam University, 12(3), 18-35.

Chantarasombat, C., Srisa-ard, B., Kuofie, M., \& Jennex, M. (2010). Using Knowledge Management to Create Model Self-Reliant Communities in Thailand. International Journal of Knowledge Management, 6(1), 62-78. https://doi.org/10.4018/jkm.2010103004

Chantarasombat, C. (2007). The Model Development of Knowledge Management for Community Organization. Doctor of Education Thesis, Faculty of Education, Mahasarakam University.

Chu-kam-nerd, W., Sangtong, E., \& Kerdtip, C. (2004). Learning Community Model: the Route to Teaching Profession for Learning during the 21st Century, Context of Schools in Thailand. Journal of Academic Hard-yai, 12(2), 123-134.

Dharma-rom-dee, S., et al. (2010). Research Art Sanctuary: Research and Development of Professional Learning Community. The Project for Academic Document of Learning for Transformation. The 8th. Nakon Patom: Amy Enterprise co. ltd.

DuFour, R., Eakey, R., \& Many, T. (2006). Learning by Doing a Handbook for Professional Learning Communities at Work. Bloomington, Indiana: Solution Tree Press.

Eastwood, K., \& Louis, K. (1992). Restructuring that Lasts: Managing the Performance Dip. Journal of School 
Leadership, 2(2), 213-224. https://doi.org/10.1177/105268469200200206

Hargreaves, A. (2003). Teaching in the Knowledge Society: Education in the Age of Insecurity. New York: Teacher College Press.

Hord, S. M. (1997). Professional Learning Communities: Communities of Continuous Inquiry and Improvement [Internet] Southwest Educational Development Laboratory. Retrieved 12 October, 2017 from http://www.sedl.org/siss/plccredit. html

Kotter, J. P., \& Cohen. D. S. (2002). The Heart of Change: Real-Life Stories of how People Change their Organizations. Boston: Harvard Business School Press.

Little, J. W., \& McLaughlin, M. W. (1993). Teachers' Work: Individuals, Colleagues, and Contexts. New York: Teachers College Press.

Ministry of Education. (2002). Guidelines for Establishment of School Curriculum. Bangkok: Kurusapa Ladprao.

Olivier, D. F., \& Hipp, K. (2006). Leadership Capacity and Collective Efficiency: Interacting to Sustain Student Learning in a Professional Learning Community. Journal of School Leadership, 16(5), 505-519. https://doi.org/10.1177/105268460601600504

Panich, W. (2012). How to develop student's learning during the 21st century. Bangkok: Sodsri-Saritwong Foundation.

Sergiovanni, T. J. (1994). Building Community in Schools. San Francisco: Jossey-Bass.

Sergiovanni, T. J., \& Starratt, R. J. (1971). Emerging Patterns of Supervision: Human Perspectives. New York: McGraw-Hill.

Sergiovanni, T. J., \& Starratt, R. J. (2007). Supervision: A Redefinition (8th ed.). New York: McGraw-Hill.

Sri-sa-ad, B. (2013). Statistical Method for Research (5th ed.). Bangkok: Suwiriyasan.

Stoll, L., \& Louis, K. S. (2007). Professional Learning Communities. London: Open University Press.

Tai-reu-kam, S. (2003). Foundation of Educational Research. Kalasin: Prasan Printing.

Thompson, S. C., Gregg, L., \& Niska, J. M. (2004). Professional Learning Communities, Leadership, and Student Learning. RMLE Online, 28(1), 1-15. https://doi.org/10.1080/19404476.2004.11658173

Wongwanich, S. (1999). The Approach and Principle of Classroom Action Researchers. Bangkok: Chulalongkorn University. 